University of Nebraska - Lincoln

DigitalCommons@University of Nebraska - Lincoln

Faculty Papers and Publications in Animal

Science

Animal Science Department

2008

\title{
Effect of Supplemental Energy Source and Frequency on Growing Calf Performance
}

\author{
T. W. Loy \\ University of Nebraska-Lincoln \\ Terry Klopfenstein \\ University of Nebraska-Lincoln, tklopfenstein1@unl.edu \\ Galen E. Erickson \\ University of Nebraska-Lincoln, gerickson4@unl.edu \\ C. N. Macken \\ University of Nebraska-Lincoln \\ J. C. Macdonald \\ Texas Agricultural Experiment Station, Amarillo
}

Follow this and additional works at: https://digitalcommons.unl.edu/animalscifacpub

Part of the Animal Sciences Commons

Loy, T. W.; Klopfenstein, Terry; Erickson, Galen E.; Macken, C. N.; and Macdonald, J. C., "Effect of Supplemental Energy Source and Frequency on Growing Calf Performance" (2008). Faculty Papers and Publications in Animal Science. 476.

https://digitalcommons.unl.edu/animalscifacpub/476

This Article is brought to you for free and open access by the Animal Science Department at DigitalCommons@University of Nebraska - Lincoln. It has been accepted for inclusion in Faculty Papers and Publications in Animal Science by an authorized administrator of DigitalCommons@University of Nebraska - Lincoln. 


\title{
Effect of supplemental energy source and frequency on growing calf performance ${ }^{1}$
}

\author{
T. W. Loy, T. J. Klopfenstein, ${ }^{2}$ G. E. Erickson, C. N. Macken, and J. C. MacDonald ${ }^{3}$ \\ Department of Animal Science, University of Nebraska, Lincoln 68583-0908
}

\begin{abstract}
Crossbred heifers $(\mathrm{n}=120 ; 265 \mathrm{~kg}, \mathrm{SD}$ $=37$ ) were fed individually $(84 \mathrm{~d})$ to determine the effect of supplement type, concentration, and frequency on intake and performance and to estimate the energy value of dry distillers grains plus solubles (DDGS) in a high-forage diet. Treatments were arranged in a $3 \times 2$ $\times 2$ factorial, with 3 supplements, 2 concentrations, and 2 frequencies of supplementation. Supplements including dry-rolled corn (DRC), DRC with corn gluten meal $(\mathrm{DRC}+\mathrm{CGM})$, and DDGS were fed at $0.21 \%$ (LOW) or $0.81 \%$ (HIGH) of BW daily and were provided daily (DAILY) or 3 times weekly (ALT). Heifers were fed to consume grass hay $(8.7 \% \mathrm{CP})$ ad libitum. Individual DMI, diet composition, BW, and ADG were used to calculate energy values for DDGS and DRC. Supplement type, concentration, frequency, and interactions were tested using the MIXED procedure of SAS, with BW included as a covariate. Supplement $\times$ concentra-
\end{abstract}

tion interactions for gain $(P=0.01)$ and $\mathrm{G}: \mathrm{F}(P<$ $0.01)$ were detected. At the LOW concentration, heifers supplemented with DDGS gained more and were more efficient $(P \leq 0.03)$ than those supplemented with DRC or DRC + CGM. No performance differences were observed $(P \geq 0.22)$ between DDGS and DRC + CGM in HIGH treatments, although both improved $(P \leq 0.01)$ gain and G:F relative to DRC. Calculated TDN content of DDGS was 18 to $30 \%$ greater than DRC. Gain and G:F were improved $(P<0.01)$ in heifers fed HIGH vs. LOW. Total intake was greater $(P<0.01)$ for HIGH than LOW, but LOW heifers consumed more hay $(P<$ $0.01)$ than HIGH. The DAILY heifers consumed more $(P<0.01)$ hay and total DM than the ALT heifers. The DAILY heifers gained more $(P<0.01)$ than ALT, but G:F was not affected $(P=0.85)$ by supplementation frequency. In a high-forage diet, DDGS has greater energy value than corn.

Key words: beef, calf, dry distillers grains, forage intake, supplementation

(0)2008 American Society of Animal Science. All rights reserved.

J. Anim. Sci. 2008. 86:3504-3510

doi:10.2527/jas.2008-0924

\section{INTRODUCTION}

Distillers grains plus solubles (DDGS) is a product of the dry milling industry (Stock et al., 2000). Nutrient content of DDGS would suggest an energy value approximately $18 \%$ greater than corn (Larson et al., 1993), although several authors have reported greater energy content in finishing diets (Ham et al., 1994; Lodge et al., 1997b). The energy value of DDGS in high-forage diets, however, is not well documented, because it has been studied primarily as a protein supplement.

Decreasing the frequency of supplement delivery can decrease costs associated with supplementation

\footnotetext{
${ }^{1}$ Contribution of the University of Nebraska Agricultural Research Division, Lincoln, Journal Series No. 14335. This research was supported in part by funds provided through the Hatch Act.

${ }^{2}$ Corresponding author: tklopfenstein1@unl.edu

${ }^{3}$ Current address: Texas Agricultural Experiment Station, Amarillo.

Received February 4, 2008.

Accepted August 6, 2008.
}

programs. In general, when protein supplements have been fed as infrequently as once every $6 \mathrm{~d}$ (Bohnert et al., 2002) or once weekly (Huston et al., 1999), grazing cattle respond similarly to their more frequently supplemented counterparts (McIlvain and Shoop, 1962; Melton and Riggs, 1965; Coleman and Wyatt, 1982; Hunt et al., 1989). This is likely due to the ability of ruminants to recycle $\mathrm{N}$ to meet microbial needs. Although fewer data are available comparing different intervals of energy supplementation, decreasing the frequency has generally resulted in varying degrees of production losses (Kartchner and Adams, 1982; Chase and Hibberd, 1989; Beaty et al., 1994). The source of supplemental energy in these studies has been corn or sorghum grain. Decreasing supplementation frequency generally necessitates feeding more grain per offering, potentially exacerbating negative effects of starch on forage digestion. Providing energy in the form of digestible fiber may improve performance of animals supplemented infrequently by alleviating negative associative effects to some degree (Fieser and Vanzant, 2004). 
Table 1. Composition (\% of DM) of supplements fed to heifers given ad libitum access to grass hay

\begin{tabular}{|c|c|c|c|c|c|c|}
\hline \multirow[b]{2}{*}{ Item } & \multicolumn{3}{|c|}{$\mathrm{LOW}^{1}$} & \multicolumn{3}{|c|}{$\mathrm{HIGH}^{2}$} \\
\hline & $\mathrm{DRC}^{3}$ & DDGS $^{3}$ & $\mathrm{DRC}+\mathrm{CGM}^{3}$ & DRC & DDGS & $\mathrm{DRC}+\mathrm{CGM}$ \\
\hline Dry distillers grains plus solubles & - & 90.3 & - & - & 94.9 & - \\
\hline Dry-rolled corn & 88.5 & - & 60.5 & 84.3 & - & 62.4 \\
\hline Corn gluten meal & - & - & 30.7 & 8.6 & - & 32.5 \\
\hline Limestone & - & - & - & 1.5 & 1.5 & 1.5 \\
\hline Salt & 3.7 & 3.7 & 3.7 & 1.0 & 1.0 & 1.0 \\
\hline Vitamin premix ${ }^{4}$ & 0.17 & 0.17 & 0.17 & 0.04 & 0.04 & 0.04 \\
\hline Mineral premix ${ }^{5}$ & 0.56 & 0.56 & 0.56 & 0.15 & 0.15 & 0.15 \\
\hline
\end{tabular}

The objectives of this research were to compare the energy value of DDGS to that of dry-rolled corn (DRC) in a high-forage diet and to evaluate whether responses to decreased supplementation frequency differ between DDGS and DRC. Our hypotheses were that DDGS would have similar energy value to DRC in a highforage diet and that DDGS may improve performance relative to DRC when supplemented every other day.

\section{MATERIALS AND METHODS}

All animal-use procedures were reviewed and approved by the Institutional Animal Care and Use Committee at the University of Nebraska-Lincoln.

One hundred twenty individually fed crossbred heifers $(265 \mathrm{~kg}, \mathrm{SD}=37)$ were used in a randomized complete block design with a $3 \times 2 \times 2$ factorial treatment arrangement $(\mathrm{n}=10)$. Factors included 3 supplements fed at 2 concentrations and at 2 frequencies. Supplements (Table 1) were based on DRC, DDGS, and DRC with corn gluten meal (DRC + CGM). Supplements were fed at $0.21 \%$ of BW daily (LOW) or $0.81 \%$ of BW daily (HIGH), either every day (DAILY) or 3 times weekly (ALT). Heifers were individually fed using Calan gates (Northwood, $\mathrm{NH}$ ) and housed in a barn open to the south.

The energy value of DDGS in high-forage diets has not been reported, and a value equal to corn (NRC, 1996) was assumed for supplement formulation. Two concentrations of supplementation, in conjunction with predicted forage intake (NRC, 1996), were predicted to produce 2 concentrations of ADG, $0.45 \mathrm{~kg} / \mathrm{d}$ (LOW) and $0.80 \mathrm{~kg} / \mathrm{d}(\mathrm{HIGH})$. The DRC and DDGS supplements were formulated to meet or exceed MP and degradable intake protein (DIP) requirements at both concentrations of feeding (NRC, 1996). The DRC + CGM supplements were formulated to supply an amount of undegradable intake protein (UIP) similar to the DDGS treatments within each concentration. Corn gluten meal ( $67 \% \mathrm{CP}, 60 \%$ of $\mathrm{CP}$ as UIP) is the primary protein fraction of corn grain and is similar to the protein in DDGS. In cases in which DIP deficiencies were predicted, urea was included, unless the predicted MP supply was sufficiently in excess to supply DIP through recycling of urea. Limestone was included in HIGH supplements to balance Ca:P, and molasses was used to decrease sorting. Supplements were designed to provide similar amounts of salt, vitamins, and trace minerals in all diets.

Heifers in ALT treatments were supplemented Monday, Wednesday, and Friday in equal portions. Weekly supplement intake was similar for ALT and DAILY within treatment. Native grass hay $(8.7 \% \mathrm{CP} ; 52 \%$ IVDMD) ground through a $12-\mathrm{cm}$ screen was fed once daily to attain ad libitum DMI, with refusals (1 to 5\%) measured once weekly. Supplements were in meal form and were fed in the morning before hay feeding. No supplement refusals were detected during the trial. All heifers received melengestrol acetate (Pfizer Inc., New York, NY) at $0.5 \mathrm{mg}$ per heifer daily with $0.23 \mathrm{~kg}$ (asfed basis) of soybean hulls as a carrier.

Heifers were fed a common diet at $1.75 \%$ of BW daily for $5 \mathrm{~d}$ at the beginning and end of the 84-d trial to minimize differences in gut fill, and BW were recorded for 3 consecutive days. Intermittent BW were measured at 28-d intervals throughout, with supplement amounts adjusted accordingly.

Because hay was offered for ad libitum intake, proportions of dietary ingredients were not consistent. Average diet composition, ADG, and DMI were used to calculate TDN values for DRC and DDGS (NRC, 1996). The reference animal used was a large-frame heifer with no implant or ionophore.

Urine samples were collected from each heifer before feeding on each of 7 consecutive days at the midpoint of the experiment, and the samples were pooled. Urine 
Table 2. Nutrient composition (\% of DM) of supplements and diets fed to heifers

\begin{tabular}{|c|c|c|c|c|c|c|}
\hline \multirow[b]{2}{*}{ Item } & \multicolumn{3}{|c|}{ LOW $^{1}$} & \multicolumn{3}{|c|}{$\mathrm{HIGH}^{2}$} \\
\hline & $\mathrm{DRC}^{3}$ & $\mathrm{DDGS}^{3}$ & $\mathrm{DRC}+\mathrm{CGM}^{3}$ & $\mathrm{DRC}$ & DDGS & $\mathrm{DRC}+\mathrm{CGM}$ \\
\hline \multicolumn{7}{|l|}{ Supplement } \\
\hline Protein, $\%$ & 22.2 & 35.4 & 32.9 & 20.0 & 28.7 & 28.9 \\
\hline Starch, \% & 62.0 & 7.7 & 43.9 & 59.0 & 8.1 & 45.3 \\
\hline $\mathrm{NDF}, \%$ & 9.7 & 27.1 & 11.6 & 9.3 & 28.5 & 12.1 \\
\hline Fat, $\%$ & 3.5 & 10.8 & 3.2 & 3.4 & 11.4 & 3.3 \\
\hline \multicolumn{7}{|l|}{ Diet } \\
\hline Protein, \% & 10.2 & 11.6 & 11.5 & 12.6 & 15.7 & 15.4 \\
\hline Starch, $\%$ & 6.4 & 0.8 & 4.5 & 19.6 & 2.8 & 14.9 \\
\hline $\mathrm{NDF}, \%$ & 64.1 & 65.9 & 64.3 & 50.0 & 55.9 & 51.2 \\
\hline Fat, $\%$ & 2.2 & 2.9 & 2.1 & 2.4 & 5.2 & 2.4 \\
\hline MP balance ${ }^{4}$ & 16 & 73 & 68 & 157 & 374 & 315 \\
\hline DIP balance ${ }^{5}$ & 8 & -21 & 2 & -37 & -170 & -19 \\
\hline \multirow{2}{*}{\multicolumn{7}{|c|}{$\begin{array}{l}{ }^{1} \text { LOW supplements fed at } 0.21 \% \text { of BW daily. } \\
{ }^{2} \mathrm{HIGH} \text { supplements fed at } 0.81 \% \text { of BW daily. }\end{array}$}} \\
\hline & & & & & & \\
\hline \multicolumn{7}{|c|}{$\begin{array}{l}{ }^{3} \mathrm{DRC}=\text { dry-rolled corn-based supplement; DDGS = dry distillers grains plus solubles-based supplement } \\
\text { DRC }+ \text { CGM = DRC supplement with corn gluten meal to supply undegradable intake protein similar to } \\
\text { DDGS. }\end{array}$} \\
\hline
\end{tabular}

was collected by restraining the heifers and stimulating them to urinate. Samples were cooled on ice, transported to the laboratory, and frozen until analysis. Purine derivative-to-creatinine ratio (PD:CR) was used as an indicator of relative changes in rumen microbial flows to the intestinal tract (Valadares et al., 1999; Shingfield, 2000; Whittet et al., 2004). Creatinine and purine derivatives were determined using HPLC (Waters Corp., Milford, MA) according to the procedure of Shingfield and Offer (1999).

Data were analyzed using the MIXED procedure (SAS Inst. Inc., Cary, NC). Heifers were started on trial in 2 groups, approximately 3 wk apart. These groups were treated as blocks in the analysis (60 heifers/block). Initial BW was used as a covariate. One heifer with low DMI and ADG was removed from analysis. Model effects included block, initial BW, supplement, concentration, frequency, and all treatment interactions. Residual error was used to test model effects.

\section{RESULTS AND DISCUSSION}

Nutrient compositions of supplements and diets varied by design (Table 2). The DDGS and DRC + CGM supplements and diets were similar in protein, whereas the DRC supplement and diet were decreased in protein. Starch was greater in DRC and DRC + CGM supplements, and diets and DDGS supplements were greater in NDF and fat. The HIGH DRC diet was 4.7 percentage units greater in starch than the DRC + CGM diet. The MP balances were positive for all diets. When DIP was deficient, there was sufficient excess MP to supply DIP through recycling (Stalker et al., 2007). There was a 3-way interaction for PD:CR ratio, and there were some 2-way interactions (Tables 3 and 4); therefore, all data are reported as simple means.

\section{Effects of Supplementation Frequency}

Decreasing supplementation frequency from daily to thrice weekly decreased $(P<0.01)$ hay DMI $(5.03$ and $4.44 \mathrm{~kg} / \mathrm{d}$ for DAILY and ALT, respectively; Table 3). Because supplements were fed as a percentage of BW, total DMI was also depressed $(P<0.01)$. Beaty et al. (1994) reported similar results for cows receiving sorghum grain and soybean meal fed daily or thrice weekly. Cows in their study that were supplemented 3 times weekly received $4.7 \mathrm{~kg}$ per offering, which was about $1 \%$ of BW per feeding. Chase and Hibberd (1989) reported no DMI differences between cows fed corn-based supplements daily or every other day. However, their average concentration of feeding for cattle supplemented infrequently $(2.6 \mathrm{~kg}$ per feeding; $\approx 0.7 \%$ of $\mathrm{BW}$ per feeding) was less than that of Beaty et al. (1994). Including the soybean hulls, supplement intakes on the days that ALT supplements were fed were 0.6 and $2.0 \%$ of BW for LOW and HIGH, respectively. The LOW concentrations are similar to those of Chase and Hibberd (1989), and the HIGH was twice the concentration fed to cows by Beaty et al. (1994).

Average daily gain (Table 3 ) was decreased by $10 \%$ ( 0.56 vs. $0.62 \mathrm{~kg} / \mathrm{d})$ by supplementing 3 times weekly compared with daily supplementation $(P<0.01)$. Similar responses have been reported in cows (Kartchner and Adams, 1982; Beaty et al., 1994) but not in heifers (Wallace, 1988). It is unclear why heifers grazing dormant blue grama range responded differently in the study by Wallace (1988), although it may be due to a decreased concentration of supplementation $(5.7 \mathrm{~kg} /$ wk; $<0.2 \%$ BW daily), or perhaps changes in grazing behavior (Melton and Riggs, 1965; Adams, 1985). In our study, DMI was decreased $12 \%$ (6.11 vs. $6.72 \mathrm{~kg} / \mathrm{d}$ ), coinciding with the $10 \%$ reduction in gain, and resulted 
in no difference $(P=0.85)$ in G:F (Table 2$)$ between heifers supplemented daily vs. 3 times weekly. We had hypothesized that DDGS may be superior to corn-based supplements when fed infrequently. Although a supplement $\times$ frequency interaction was not detected $(P=$ 0.13 ), DRC seemed to result in the least reduction in ADG when fed less frequently. Decreasing supplementation frequency depressed ADG by $10.5 \%$ for DDGS, $15.0 \%$ for DRC + CGM, but did not change ADG for DRC.

\section{Effects of Supplementation Concentration}

A substitution effect was observed as hay DMI (Table 3$)$ was less $(P<0.01)$ at the high than at the low concentration of supplementation (4.99 and $4.47 \mathrm{~kg} / \mathrm{d}$ for LOW and HIGH, respectively). Supplement intake, formulated to be 0.21 and $0.81 \%$ of BW daily, was 0.21 and $0.79 \%$ of BW daily for LOW and HIGH, respectively $(P<0.01)$. Other data have shown forage replacement effects as supplement intake exceeded $0.25 \%$ of BW daily (Bowman and Sanson, 1996) or 0.50\% of BW daily (Horn and McCollum, 1987). Moore et al. (1999) reported that forage intake was decreased when supplemental TDN intake exceeded $0.7 \%$ of BW daily, forage TDN:CP was less than 7, or when forage DMI without supplementation exceeded $1.75 \%$ of BW daily. All diets in this study had TDN:CP ratios less than 7. In spite of decreased forage intake, total DMI was greater $(P<0.01)$ for heifers in HIGH treatments.

\section{Effects of Supplement Type}

Hay DMI (Table 3$)$ did not differ $(P=0.27)$ among supplements $(4.67,4.70$, and $4.83 \mathrm{~kg} / \mathrm{d}$ for DDGS, DRC, and DRC + CGM, respectively). Ruminal starch digestion has been shown to decrease fiber digestion, and some authors have shown differing effects of starch and fiber-based supplements on forage utilization (Grigsby et al., 1993; Garcés-Yépez et al., 1997; Fieser and Vanzant, 2004). However, these effects may be partially precipitated by changes in DIP requirements resulting from supplementation, and formulating supplements to meet DIP requirements may alleviate some of the negative associative effect (Bodine and Purvis, 2003). In agreement with these data, a review by Moore et al. (1999) suggested that supplement source had little effect on changes in forage DMI.

\section{Supplement $\times$ Concentration Interactions}

Supplement $\times$ concentration interactions were detected $(P \leq 0.01)$ for ADG and G:F (Table 3). Heifers in LOW treatments supplemented with DDGS gained faster and were more efficient $(P<0.01)$ than those fed DRC or DRC + CGM, which were similar $(P=0.20)$. At the HIGH feeding concentration, DDGS and DRC + CGM had similar $(P=0.85)$ ADG and $\mathrm{G}: \mathrm{F}$, and both were improved $(P<0.01)$ relative to DRC. Similar

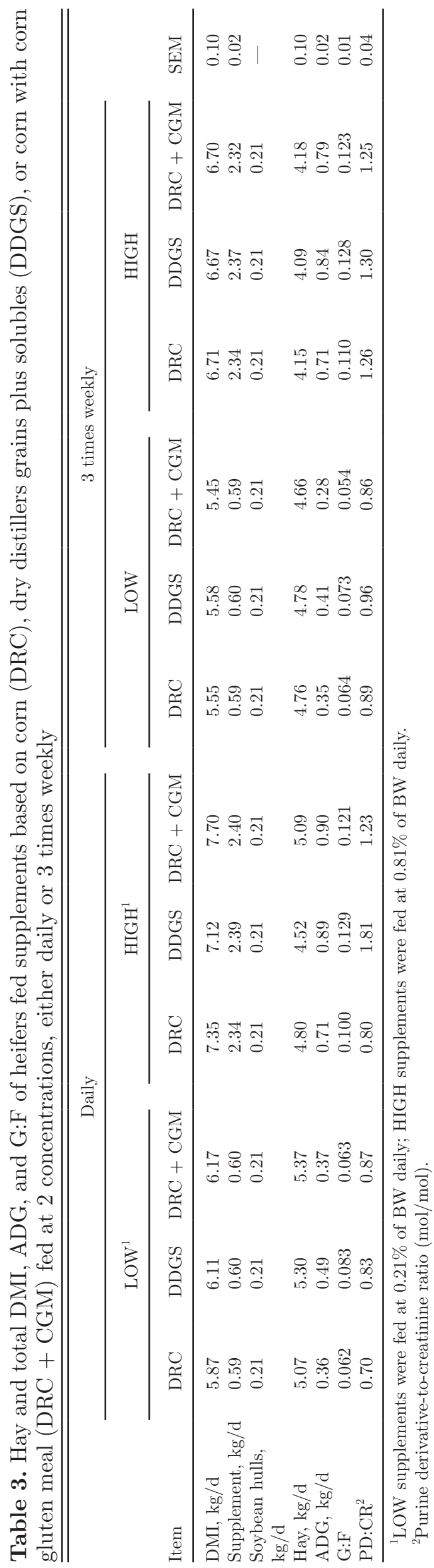


Table 4. Statistical probabilities $\left(P\right.$-values) for effects of frequency ${ }^{1}(\mathrm{~F})$, concentration $^{2}(\mathrm{C})$, supplement type ${ }^{3}(\mathrm{~S})$, and their interactions

\begin{tabular}{|c|c|c|c|c|c|c|c|}
\hline Item & $\mathrm{F}$ & $\mathrm{C}$ & $\mathrm{S}$ & $\mathrm{F} \times \mathrm{C}$ & $\mathrm{C} \times \mathrm{S}$ & $\mathrm{F} \times \mathrm{S}$ & $\mathrm{F} \times \mathrm{C} \times \mathrm{S}$ \\
\hline DMI & $<0.01$ & $<0.01$ & 0.27 & 0.42 & 0.25 & 0.33 & 0.57 \\
\hline Supplement & 0.28 & $<0.01$ & 0.77 & 0.79 & 0.93 & 0.94 & 0.90 \\
\hline Hay & $<0.01$ & $<0.01$ & 0.27 & 0.45 & 0.23 & 0.37 & 0.53 \\
\hline $\mathrm{ADG}$ & $<0.01$ & $<0.01$ & $<0.01$ & 0.96 & $<0.01$ & 0.13 & 0.89 \\
\hline $\mathrm{G}: \mathrm{F}$ & 0.85 & $<0.01$ & $<0.01$ & 0.46 & 0.01 & 0.23 & 0.85 \\
\hline PD: $\mathrm{CR}^{4}$ & 0.53 & $<0.01$ & $<0.01$ & 0.50 & 0.14 & 0.01 & 0.03 \\
\hline
\end{tabular}

performance between DDGS and DRC + CGM at the HIGH concentration may suggest a response to UIP. However, all supplements were formulated to meet or exceed MP requirements, and an MP deficiency would be more likely at the LOW supplement concentration. There was no indication of an MP deficiency at the LOW concentration, because ADG and G:F for the DRC treatment were similar to the DRC + CGM treatment. Increased starch intake (DRC treatment) at the HIGH concentration may have resulted in a negative associative effect, causing decreased fiber digestibility (Fieser and Vanzant, 2004). Perhaps replacement of some starch with gluten meal in the DRC + CGM treatment alleviated some of the negative effects at the HIGH concentration of feeding. If a negative associative effect did occur, one could expect forage intake to be disproportionately depressed by starch-containing supplements. However, a source $\times$ concentration interaction was not observed $(P=0.23)$ for the forage intake. Thus, a depressing effect from the starch in the DRC treatment did not exist or a similar depressing effect must have existed for DDGS. High lipid intakes have been shown to decrease fiber digestion (Pavan et al., 2007). Total dietary lipid concentrations within the HIGH treatments were $5.2 \%$ for DDGS, $2.4 \%$ for DRC, and $2.4 \%$ for DRC + CGM.

\section{Prediction of Energy Value of Supplements}

The nutrient content of DDGS can account for approximately $18 \%$ greater energy value than corn (Larson et al., 1993). However, the nutrient content alone cannot account for associative effects, positive or negative, that may exist. In finishing diets, DDGS has been shown to have a decreased energy value than when distillers grains were fed wet (Ham et al., 1994; Lodge et al., 1997a), and DDGS had $21 \%$ greater $\mathrm{NE}_{\mathrm{g}}$ than dry-rolled corn.

Block et al. (2006) showed that the NRC (1996) model, based on the NE system, does not accurately predict performance of calves on forage-based diets. It was necessary to use the $\mathrm{NE}$ adjusters in level I of the NRC (1996) model to predict actual cattle performance. Because cattle performance was underpredicted at low rates of gain, it was necessary to increase the NE adjusters above $100 \%$, and at greater rates of gain, it was necessary to decrease the adjusters below $100 \%$. We used this concept of adjusting the NE adjusters for the energy (TDN) calculations in this study. Because we had high and low gain controls (DRC or DRC + CGM) in this study, those controls were used to determine the NE adjusters rather than directly using those from Block et al. (2006).

Observed DMI and ADG were input into the NRC (1996) model (level I). Because ADG and G:F were similar for the LOW supplementation concentration, the mean values of DMI and ADG of DRC and DRC + CGM, for daily and 3 times weekly, were used as the control evaluation. Because the DRC + CGM supplement produced greater $\mathrm{ADG}$ and $\mathrm{G}: \mathrm{F}$ than $\mathrm{DRC}$, the ADG and G:F for DRC + CGM were used as the control for the HIGH supplementation concentration. The greater $\mathrm{ADG}$ and $\mathrm{G}: \mathrm{F}$ suggest less negative associate effect from the starch (starch was 30\% less in the DRC + CGM treatment). This allowed calculation of the TDN value of the corn in the DRC treatment. It was necessary to adjust the $\mathrm{NE}$ adjusters (both $\mathrm{NE}_{\mathrm{m}}$ and $\mathrm{NE}_{\mathrm{g}}$ ) to $102 \%$ to accurately predict ADG at the LOW concentration of supplement. The hay was $52 \%$ TDN (IVDMD), and all other ingredients were $90 \%$ TDN. At the HIGH concentration of supplement, the NE adjusters were at $95.2 \%$. The need to change the adjusters with increasing ADG has been documented (Block et al., 2006).

By interpolation between the ADG values for the controls, the NE adjusters were set at $100.8 \%$ for the LOW DDGS supplement. The TDN was then adjusted to $120 \%$ to predict actual ADG. At the HIGH DDGS supplement concentration, the NE adjusters were at $95 \%$ and the resulting TDN was $95.8 \%$. Using the same logic, the NE adjusters were set at $97.2 \%$ for the HIGH DRC supplement and the TDN was adjusted to $81 \%$. Given these calculations, the TDN value of DRC decreased from $90 \%$ at the LOW supplement concentration to $81 \%$ at the HIGH supplement concentration. This is likely due to the negative effect of starch and pH on cellulolytic activity (Loy et al., 2007). Although the decline in TDN was charged to the corn in our cal- 
culations, the decline in digestibility (TDN) was likely due to a decline in the digestibility of fiber of the hay. About $30 \%$ of the corn was replaced by CGM in the DRC + CGM treatment. This replacement of starch with high UIP likely explains the greater ADG and G:F for the DRC + CGM treatment compared with the DRC treatment.

The TDN concentration of DDGS declined from $120 \%$ at the LOW supplement concentration to $95.8 \%$ at the HIGH supplement concentration. We theorize that this decline is due to the fat content of the DDGS and the subsequent effect on ruminal cellulolytic activity (Loy et al., 2007). The fat of the HIGH DDGS diet was about $5.2 \%$. At the LOW supplement concentration, DDGS had over $130 \%$ of the energy value of DRC and at the HIGH concentration, $118 \%$ the value of DRC. Apparently, the fat and UIP are excellent energy sources, especially at the LOW supplement concentration, compared with the starch in DRC.

\section{Purine Derivatives}

Purines can be detected in duodenal flow and are used to estimate microbial production (Broderick and Merchen, 1992). Purine degradation products are excreted in the urine and can be used to estimate microbial production (Valadares et al., 1999). Urinary creatinine is directly related to muscle mass and is excreted at a constant rate (Hayden et al., 1992). Therefore, PD:CR in spot urine samples can be used to estimate microbial production. Shingfield (2000) concluded that with current understanding, purine degradation products may be used to determine relative differences in microbial production - absolute values will require more research. We are therefore reporting PD:CR as an indicator of treatment effects on microbial production.

There was a 3 -way and a 2-way interaction for PD:CR (Table 3). Except for the HIGH supplement concentration fed daily, there was no effect of supplement type. In addition, PD:CR was greater at the HIGH supplementation concentration than at the LOW supplementation concentration (1.28 vs. 0.85 ), which would be expected because of greater overall fermentable energy intake. When fed daily at HIGH supplementation concentration, the PD:CR was greater for DDGS-supplemented heifers than for DRC-supplemented heifers (1.56 vs. 1.03; $P<0.01)$. The reason for this is not obvious, because it did not occur when heifers were fed 3 times/ wk. We conclude that PD:CR ratios suggest equivalent amounts of microbial growth across supplement type and greater microbial growth when supplements were fed at the HIGH concentration. There are likely several factors that would influence ruminally available energy and subsequent microbial growth. Corn is about $67 \%$ starch, and the starch would be expected to be primarily degraded in the rumen. This starch degradation could also lower $\mathrm{pH}$, which could decrease fiber digestion (Loy et al., 2007) and microbial efficiency (NRC, 1996).
The DDGS-supplemented calves gained more BW than the DRC-supplemented heifers but did not have greater PD:CR ratios. Much of the energy in DDGS is in the form of lipid and undegradable protein. These 2 sources of energy to the animal would not be ruminally degraded and therefore would not supply energy for microbial growth.

There was no effect of frequency of feeding on PD:CR ratios. Urine samples were collected daily over a complete week, which should compensate for different amounts of ruminally available energy on alternate days. Intakes and ADG were both less for calves supplemented 3 times weekly, but this was not reflected in $\mathrm{PD}: \mathrm{CR}$ ratios.

In summary, supplementing DDGS or DRC 3 times weekly decreased forage intake and BW gain compared with daily supplementation. The DDGS improved BW gain and G:F compared with DRC. The calculated TDN of DDGS was 118 to $130 \%$ the value of corn when fed as a supplement to a grass-hay diet.

\section{LITERATURE CITED}

Adams, D. C. 1985. Effect of time of supplementation on performance, forage intake and grazing behavior of yearling beef steers grazing Russian wild ryegrass in the fall. J. Anim. Sci. 61:1037-1042.

Beaty, J. L., R. C. Cochran, B. A. Lintzenich, E. S. Vanzant, J. L. Morrill, R. T. Brandt Jr., and D. E. Johnson. 1994. Effect of frequency of supplementation and protein concentration in supplements on performance and digestion characteristics of beef cattle consuming low-quality forages. J. Anim. Sci. $72: 2475-2486$.

Block, H. C., T. J. Klopfenstein, and G. E. Erickson. 2006. Evaluation of average daily gain prediction by level one of the 1996 National Research Council beef model and development of net energy adjusters. J. Anim. Sci. 84:866-876.

Bodine, T. N., and H. T. Purvis II. 2003. Effects of supplemental energy and/or degradable intake protein on performance, grazing behavior, intake, digestibility, and fecal and blood indices by beef steers grazed on dormant native tallgrass prairie. J. Anim. Sci. 81:304-317.

Bohnert, D. W., C. S. Schauer, and T. DelCurto. 2002. Influence of rumen protein degradability and supplementation frequency on performance and nitrogen use in ruminants consuming lowquality forage: Cow performance and efficiency of nitrogen use in wethers. J. Anim. Sci. 80:1629-1637.

Bowman, J. G. P., and D. W. Sanson. 1996. Starch- or fiber-based energy supplements for grazing ruminants. Proc. West. Sect. Am. Soc. Anim. Sci. 47(Suppl. 1):118-135.

Broderick, G. A., and N. R. Merchen. 1992. Markers for quantifying microbial protein synthesis in the rumen. J. Dairy Sci. 75:2618-2632.

Chase, C. C., and C. A. Hibberd. 1989. Effect of level and frequency of maize supplementation on the utilization of low-quality hay by beef cows. Anim. Feed Sci. Technol. 24:129-139.

Coleman, S. W., and R. D. Wyatt. 1982. Cottonseed meal or small grain forages as protein supplements fed at different intervals. J. Anim. Sci. 55:11-17.

Fieser, B. G., and E. S. Vanzant. 2004. Interactions between supplement energy source and tall fescue hay maturity on forage utilization by beef steers. J. Anim. Sci. 82:307-318.

Garcés-Yépez, P., W. E. Kunkle, D. B. Bates, J. E. Moore, W. W. Thatcher, and L. E. Sollenberger. 1997. Effects of supplemental energy source and amount on forage intake and performance by 
steers and intake and diet digestibility by sheep. J. Anim. Sci. 75:1918-1925.

Grigsby, K. N., M. S. Kerley, J. A. Paterson, and J. C. Weigel. 1993. Combinations of starch and digestible fiber in supplements for steers consuming a low-quality bromegrass hay diet. J. Anim. Sci. 71:1057-1064.

Ham, G. A., R. A. Stock, T. J. Klopfenstein, E. M. Larson, D. H. Shain, and R. P. Huffman. 1994. Wet corn distillers byproducts compared with dried corn distillers grains with solubles as a source of protein and energy for ruminants. J. Anim. Sci. $72: 3246-3257$.

Hayden, J. M., W. G. Bergen, and R. A. Merkel. 1992. Skeletal muscle protein metabolism and serum growth hormone, insulin, and cortisol concentrations in growing steers implanted with estradiol-17 $\beta$, trenbolone acetate, or estradiol-17 $\beta$ plus trenbolone acetate. J. Anim. Sci. 70:2109-2119.

Horn, G. W., and F. T. McCollum. 1987. Energy supplementation of grazing ruminants. Page 125-136 in Proc. Grazing Livest. Nutr. Conf. Univ. Wyoming, Laramie.

Hunt, C. W., J. F. Parkinson, R. A. Roeder, and D. G. Faulk. 1989. The delivery of cottonseed meal at three different time intervals to steers fed low-quality grass hay: Effects on digestion and performance. J. Anim. Sci. 67:1360-1366.

Huston, J. E., H. Lippke, T. D. A. Forbes, J. W. Holloway, and R. V. Machen. 1999. Effects of supplemental feeding interval on adult cows in western Texas. J. Anim. Sci. 77:3057-3067.

Kartchner, R. J., and D. C. Adams. 1982. Effects of daily and alternate day feeding of grain supplements to cows grazing fallwinter range. Proc. West. Sect. Am. Soc. Anim. Sci. 33:308. (Abstr.)

Larson, E. M., R. A. Stock, T. J. Klopfenstein, M. H. Sindt, and R. P. Huffman. 1993. Feeding value of wet distillers byproducts for finishing ruminants. J. Anim. Sci. 71:2228-2236.

Lodge, S. L., R. A. Stock, T. J. Klopfenstein, D. H. Shain, and D. W. Herold. 1997a. Evaluation of corn and sorghum distillers byproducts. J. Anim. Sci. 75:37-43.

Lodge, S. L., R. A. Stock, T. J. Klopfenstein, D. H. Shain, and D. W. Herold. 1997b. Evaluation of wet distillers composite for finishing ruminants. J. Anim. Sci. 75:44-50.

Loy, T. W., J. C. MacDonald, T. J. Klopfenstein, and G. E. Erickson. 2007. Effect of distillers grains or corn supplementation frequency on forage intake and digestibility. J. Anim. Sci. $85: 2625-2630$

McIlvain, E. H., and M. C. Shoop. 1962. Daily versus every-thirdday versus weekly feeding of cottonseed cake to beef steers on winter range. J. Range Manage. 15:143-149.
Melton, A. A., and J. K. Riggs. 1965. Frequency of feeding protein supplement to range cattle. Agric. Exp. Stn. Bull. 1025. Texas A \& M Univ., College Station.

Moore, J. E., M. H. Brant, W. E. Kunkle, and D. I. Hopkins. 1999. Effects of supplementation on voluntary forage intake, diet digestibility, and animal performance. J. Anim. Sci. 77(Suppl. 2):122-135.

NRC. 1996. Nutrient Requirements of Beef Cattle. 7th ed. Natl. Acad. Press, Washington, DC.

Pavan, E., S. K. Duckett, and J. G. Andreae. 2007. Corn oil supplementation to steers grazing endophyte-free tall fescue. I. Effects on in vivo digestibility, performance, and carcass traits. J. Anim. Sci. 85:1330-1339.

Shingfield, K. J. 2000. Estimation of microbial protein supply in ruminant animals based on renal and mammary purine metabolite excretion. A review. J. Anim. Feed Sci. 9:169-212.

Shingfield, K. J., and N. W. Offer. 1999. Simultaneous determination of purine metabolites, creatinine, and pseudouridine in ruminant urine by reversed-phase high-performance liquid chromatography. J. Chromatogr. B Analyt. Technol. Biomed. Life Sci. 723:81-94.

Stalker, L. A., T. J. Klopfenstein, D. C. Adams, and G. E. Erickson. 2007. Urea inclusion in distillers dried grains supplements. Prof. Anim. Sci. 23:390-394.

Stock, R. A., J. M. Lewis, T. J. Klopfenstein, and C. T. Milton. 2000. Review of new information on the use of wet and dry milling feed byproducts in feedlot diets. Proc. Am. Soc. Anim. Sci. 1999. http://www.asas.org/symposia/9899proc/0924.pdf Accessed Jan. 7, 2008.

Valadares, R. F. D., G. A. Broderick, S. C. Valadares Filho, and H. Cramer. 1999. Effect of replacing alfalfa silage with high-moisture corn on ruminal protein synthesis estimated from excretion of total purine derivatives. J. Dairy Sci. 82:2686-2696.

Wallace, J. D. 1988. Supplemental feeding options to improve livestock efficiency on rangelands. Pages 92-100 in Achieving Efficient Use of Rangeland Resources. R. S. White, and R. E. Short, ed. Proc. Fort Koegh Res. Symp., Miles City, MT. Montana Agric. Exp. Stn., Bozeman.

Whittet, K. M., T. J. Klopfenstein, G. E. Erickson, T. W. Loy, R. A. McDonald, and K. W. Creighton. 2004. Evaluation of the variability in urinary creatinine and purine derivative excretion in growing and finishing heifers. J. Anim. Sci. 82(Suppl. 2):90. (Abstr.) 